\title{
Hubungan Sanitasi Rumah dengan Kejadian Penyakit Common Cold di Wilayah Kerja Puskesmas Bandar Kabupaten Bener Meriah
}

\author{
Afdalul Magfirah, Lia Muslima, M.Sabdi \\ Stikes Payung Negri Aceh Darussalam
}

\begin{abstract}
Abtrak
Latar Belakang: Common Cold adalah infeksi yang terjadi di nasofaring dan hidung, salah satu upaya untuk mencegah penyakit Common Cold adalah kebersihan lingkungan rumah atau sanoitasi. Di Aceh jumlah penyakit common cold masuk dalam peringkat pertama dari 10 besar penyakit terbanyak.

Metode: Jenis penelitian ini bersifat diskriptif analitik dengan desain cross sectional. Populasi dalam penelitian ini adalah seluruh pengujung puskesmas berobat di puskesmas Bandar Kabupaten Bener Meriah sebanyak 138 KK. Sampel diambil dengan teknik purposive sampling dimana jumlah sampel 58 responden. Penelitian dilakukan dengan menggunakan kuesioner.

Hasil: Hasil penelitian ini menunjukkan bahwa dari 58 responden mayoritas sanitasi rumah responden Tidak Memenuhi Syarat sebanyak 43 responden (74,1\%), dan mayoritas kejadian Common Cold sebanyak 40 responden (69,0\%). Uji statistik Chi Square dilakukan untuk mengetahui hubungan sanitasi rumah dengan kejadian common cold diperoleh p-value 0,000 (P $\leq 0,05)$. Kesimpulan: Hal ini menunjukkan secara statistis bahwa terdapat hubungan yang bermakna antara sanitasi rumah dengan kejadian common cold, Disarankan kepada responden agar dapat meningkatkan atau menjaga sanitasi rumah yang sehat sehingga terhindar dari kejadian penyakit common cold.
\end{abstract}

Kata kunci: Common Cold ,Perilaku Merokok, Sanitasi

\begin{abstract}
Background: Common cold is a primary infection of the nasopharynx and nose Sanitation is an effort to prevent disease that focuses on activities for the health of the human environment.This type of research is analytic descriptive with cross sectional design.
\end{abstract}

Method: The population in this study were all patients seeking treatment at the Puskesmas Bandar, Bener Meriah Regency, as many as 138 families. Sampling was carried out using the Slovin formula where the number of samples was 58 respondents. The study was conducted from 25 November to 5 December 2020 using a questionnaire.

Result: The results of this study indicate that of the 58 respondents the majority of respondents' home sanitation does not meet the requirements as many as 43 respondents (74.1\%), and the majority of common cold incidents are 40 respondents $(69.0 \%)$. Based on the results of the Chi Square statistical test and at the 95\% level of confidence, it was carried out to determine the relationship between home sanitation and the incidence of common cold, the P value was obtained $(P \leq 0.05)$.

Conlusion: This shows statistically that there is a significant relationship between home sanitation and common cold.

Key Words: common cold,Smoking Behavior, sanitation. 


\section{PENDAHULUAN}

IPM atau yang disebut sebagai Indeks Pembangunan Manusia, sangat didukung oleh keadaan sehat sumber daya manusia di suatu negara, dimana kesehatan ini merupakan investasi dan hak dasar setiap manusia. Salah satu upaya menciptakan kehidupan yang sehata adalah dengan melakukan sanitasi. Menurut WHO pengertian sanitasi adalah upaya untuk mencegah timbulnya penyakit yang dititik beratkan pada usaha kebersihan lingkungan sekitar. Pengertian lain disebutkan bahwa sanitasi merupakan upaya monitoring terhadap lingkungan fisik disekitar manusia yang dapat mengganggu kesehatan jasmani hingga dapat menimbulkan penyakit. Lingkungan yang paling dekat untuk dijaga kebersihannya adalah lingkungan sekitar rumah dimana pengertian rumah adalah bangunan rumah yang dapat ditinggali, sarana pengembanganan keluarga, menggambarkan harkat dan martabat, dan juga aset pemiliknya ${ }^{1}$.

Common cold, atau nasofaringitis termasuk kelompok non spesifik atau "flu biasa". Infeksi ini diakibatkan oleh virus yang menyerang saluran pernapasan atas (hidung) ${ }^{2}$ yang bisa berlangsung selama 1 sampai 2 minggu. WHO memperkirakan insidensi common cold menyebabkan kematian mencapai $15 \%-20 \%$ pertahun pada balita diatas 40/1000 kelahiran hidup ${ }^{3}$. Permasalahan dunia berkaitan dengan penyakit berbasis lingkungan yang masih belum bisa diatasi dan sering terjadi sampai saat ini salah satunya adalah pneumonia ${ }^{4}$.

Sesuai dengan yang telah dilakukan oleh peneliti sebelumnya didapatkan hubungan signifikan antara faktor sanitasi rumah dan penyakit ISPA $^{5}$. Pada penelitian yang lain dikemukakan, sanitasi rumah memiliki hubungan yang erat dengan terjadinya Common cold yang melanda penduduk Indonesia terutama pada usia balita dan anakanak. Penelitian ini didukung juga oleh penelitian yang mengemukakan bahwa tersedianya jendela dapur dapat mempengaruhi kejadian ISPA ${ }^{6}$.

Penelitian di Puskesmas Gorontalo dihasilkan bahwa responden yang mengalami Common cold berjumlah $86 \%$ dan yang tidak mengalami Common cold berjumlah 14\% ${ }^{7}$. Variabel-variabel yang diteliti adalah ventilasi rumah (memenuhi syarat $37 \%$ dan tidak $63 \%$ ), kepadatan hunian (tidak memenuhi syarat $55.5 \%$ dan memenuhi syarat $44.5 \%$ ), pencahayaan (alami $66.5 \%$ dan buatan $33.5 \%$ ), dan status perokok responden (merokok $76.5 \%$ dan tidak merokok sebesar 23.5\%). Dari 4 variabel yang telah di teliti, disimpulkan bahwa hanya pencahayaan yang berkaitan erat dengan Common cold.

Penelitian lain yang dilakukan di masyarakat Desa Kalianget Timur, menunjukkan bahwa kepadatan hunian $(p=0,004)$ berhubungan secara signifikan dengan kejadian ISPA dan sedangkan luas ventilasi $(p=0,239)$, suhu udara $(p=0,750)$, kelembaban $(\mathrm{p}=0,720)$, serta pencahayaan $(\mathrm{p}=0,612)$ tidak berpengaruh secara signifikan dengan ISPA ${ }^{8}$. Untuk itu disaranak bagi masyarakat yang memiliki kepadatan hunian yang tidak memenuhi syarat, diharapkan dapat membatasi jumlah penghuni yang tidur dikamar balita, misalnya ayah ketika tidur sebaiknya berada di ruang yang berbeda untuk meminimasi terjadinya ISPA pada balita.Di Aceh jumlah penyakit common cold menduduki peringkat pertama dari 10 besar penyakit terbanyak, yaitu Common Cold sebanyak 18.601 kasus, ISPA 14.945 Kasus, Hipertensi 14.356 kasus, Penyakit kelainan pada lambung 7.414 kasus, Diabetes Melitus (NIDDM) 6.278 kasus, Penyakit pada sistem Jaringan otot dan Jar. Pengikat (gout Artritis) 5.795 kasus, penyakit kulit alergi 5.110 kasus, Diabetes Melitus (IDDM) 4.181 kasus, Dispepsia 2.657 kasus, dan Pulpitis 2.342 kasus ${ }^{9}$.

Berdasarkan survei awal yang didapatkan dari Dinkes Bener Meriah dan Puskesmas Kecamatan Bandar bahwa penyakit Common cold di Wilayah Kerja Puskesmas dalam 2 tahun belakangan mengalami kenaikan Tahun 2018 jumlah kasus sebanyak 256 jiwa meningkat menjadi 303 jiwa pada tahun 2019 (Data Survei Awal Puskesmas Bandar 2020). Survei observasi awal di rumah penduduk bahwa rumah penduduk sebagian ada yang belum permanen. Diantaranya juga dijumpai lantai yang belum memenuhi syarat kesehatan. Berdasakan hasil wawancara yang dilakukan oleh penulis terhadap 10 pengujung puskesmas, 8 dari 10 pengujung puskesmas mengatakan bahwa mereka sering sakit, batuk, dan filek, kemudian 6 dari 10 pengujung puskesmas mengatakan bahwa langit-langit rumah mereka banyak kotoran dan jarang dibersihkan, kemudian 5 dari 10 Pengujung puskesmas mengatakan penyebab penyakitnya karena kondisi rumah yang kurang sehat. 


\section{METODE}

Penelitian dilakukan dengan pendekatan cross sectional. Populasi diambil dari seluruh pengujung puskesmas yang berobat di wilayah kerja Puskesmas Bandar Kabupaten Bener Meriah dari bulan Januari hinga Mei 2020 yang berjumlah total 138 KK. Teknik pengambilan sample pada penelitian ini adalah secara purposive sampling. Analisis ini dilakukan terhadap variabel sanitasi rumah dan kejadian Common cold. Data penelitian digambarkan dalam tabel dan narasi untuk menggambarkan seberapa besar proporsi dari setiap karakteristik yang ditemukan pada sampel untuk setiap variabel yang diteliti, dan dilanjutkan dengan Analisa Bivariat untuk mencari hubungan kedua variabel tersebut. Analisa yang digunakan adalah hasil tabulasi silang penyajian data yang digunakan berupa tabel frekuensi univariat dan bivariat melihat adanya hubungan antara variabel bebas dan terika tadalah dengan menggunakan uji Chi square dengan menggunakan nilai CI 95\%. .

\section{HASIL}

\section{Analisis Univariat}

Dibawah ini merupakan hasil analisis univariat dari keadaan sanitasi rumah dan Common Cold pada pengujung puskesmas di wilayah kerja Puskesmas Bandar.

\section{Tabel 1. Distribusi Frekuensi Sanitasi Rumah dan Kejadian Common Cold pada pengujung puskesmas di wilayah kerja puskesmas Bandar}

\begin{tabular}{lcc}
\hline \multicolumn{1}{c}{ Variabel } & $\begin{array}{c}\text { Jumlah } \\
\text { (n) }\end{array}$ & Persentase (\%) \\
\hline $\begin{array}{l}\text { Keadaan } \\
\text { sanitas rumah } \\
\text { Tdk Memenuhi }\end{array}$ & 43 & 74,1 \\
$\begin{array}{l}\text { Syarat } \\
\text { Memenuhi }\end{array}$ & 15 & 25,9 \\
$\begin{array}{l}\text { Syarat } \\
\text { Common Cold }\end{array}$ & & \\
Ya & 40 & 69,0 \\
Tidak & 18 & 31,0 \\
\hline Jumlah & 58 & 100,0 \\
\hline
\end{tabular}

(Sumber: Data Primer Diolah Tahun 2020)

Berdasarkan tabel 1. dari 58 responden proporsi tertinggi keadaan sanitasi rumah responden adalah orang yang tidak memenuhi syarat sebanyak 43 responden $(74,1 \%)$. Sedangkan proporsi tertinggi pada kejadian common cold adalah responden yang mengalami common cold sebesar $40 \quad(69 \%)$ responden.

\section{Analisis Bivariat}

Di bawah ini merupakan hasil analisis hubungan antara 2 variabel yang di uji dengan chi square untuk mengetahui hubungan antara keadaan sanitasi rumah dengan kejadian Common cold pada pengujung puskesmas di Wilayah Kerja Puskesmas Bandar.

Tabel 2. Hubungan Sanitasi rumah dengan Kejadian Common Cold pada pengujung puskesmas di wilayah kerja puskesmas Bandar

\begin{tabular}{|c|c|c|c|c|c|c|c|}
\hline \multirow[t]{3}{*}{$\begin{array}{l}\text { Sanitasi } \\
\text { Rumah }\end{array}$} & \multicolumn{4}{|c|}{$\begin{array}{c}\text { Kejadian Common } \\
\text { Cold }\end{array}$} & \multirow{2}{*}{\multicolumn{2}{|c|}{ Jumlah }} & \multirow[t]{3}{*}{$\begin{array}{c}\mathbf{P} \\
\text { Value }\end{array}$} \\
\hline & \multicolumn{2}{|c|}{ Tidak } & \multicolumn{2}{|c|}{ Ya } & & & \\
\hline & $\mathbf{F}$ & $\%$ & $\mathbf{F}$ & $\%$ & $\mathbf{F}$ & $\%$ & \\
\hline $\begin{array}{l}\text { Tidak } \\
\text { Memenuhi } \\
\text { Syarat }\end{array}$ & 5 & 11,6 & 38 & 88,4 & 43 & 100 & \\
\hline $\begin{array}{l}\text { Memenuhi } \\
\text { Syarat }\end{array}$ & 13 & 86,7 & 2 & 13,3 & 15 & 100 & 0,000 \\
\hline Jumlah & 18 & 31,0 & 40 & 69,0 & 58 & 100 & \\
\hline
\end{tabular}

Berdasarkan hasil uji statistik terlihat bahwa terdapat hubungan antara keadaan sanitasi rumah dan kejadian common cold pada pengunjung puskesmas di Wilayah Kerja Bandar, degan $p$-value $=0,000$ (p-value $>$ 0,005).

\section{PEMBAHASAN}

Dari 58 responden mayoritas sanitasi rumah responden yang tidak memenuhi persyaratan sebanyak 43 responden $(74,1 \%)$. Sesuai dengan data yang didapatkan dilapangan kondisi sanitasi rumah responden memang sangat banyak yang tidak memenuhi syarat seperti tidak adanya sarana pembuangan air limbah, jarak sumur yang telalu dekat dengan septi tank, dan bahkan responden tidak memiliki sarana tempat pembuangan sampah.

Berdasarkan data yang diperoleh dari hasil tabulasi bahwa dari 58 responden mayoritas kejadian Common Cold sebanyak 40 responden (69,0\%). Tingginya angka kejadian Common Cold ini didapatkan dari responden dengan kondisi yang dalam waktu dekat ini 
responden sering mengeluh batuk, pilek dan demam, dan bahkan penderitanya mengenai keseluruh anggota keluarga serumah. Penyakit Common cold adalah infeksi utama pada nasofaring dan hidung dengan gejala mengeluarkan cairan dimana infeksi ini banyak terjadi pada balita dan anak ${ }^{10}$. Anak usia 6 tahun sering mengalami keluhan batuk dan pilek dengan frekuensi 6-8 kali setiap tahunnya. Common cold, tergolong Infeksi saluran pernapasan atas (ISPA) non spesifik atau "flu biasa"2. Penyebutan penyakit Commond cold mempunyai perbedaan berdasarkan tingkat keparahannya, jika infeksinya ringan maka disebut sebagai 'cold', ditingkat lebih parah disebut 'flu'. Common Cold disebabkan oleh beberapa virus seperti Coronavirus, human respiratory syncytial virus yang dikenal sebagai virus influenza, dan jenis virus lainnya. Virus jenis ini mempunyai banyak jenisnya dan virus baru terus diidentifikasi ${ }^{11}$.

Tingginya angka kejadian Common Cold ini disebabkan karena kondisi sanitasi rumah responden memang sangat banyak yang tidak memenuhi syarat seperti tidak adanya sarana pembuangan air limbah, jarak sumur yang telalu dekat dengan septi tank, dan bahkan responden tidak memiliki sarana tempat pembuangan sampah.

Dari 43 responden dengan sanitasi rumah tidak memenuhi syarat sebanyak $38(88,4 \%)$ responden common cold, sedangkan dari 15 responden dengan sanitasi rumah memenuhi syarat ternyata sebanyak $13 \quad(86,7 \%)$ responden tidak common cold. Salah satu determinan yang menyebabkan kejadian common cold adalah lingkungan fisik dan kebersihan lingkungan rumah yang tidak memenuhi persyaratan kesehatan. Aspekaspek yang tidak memenuhi persyaratan kesehatan dilihat dari lingkungan dalam rumah yang kotor dan kumuh, ventilasi yang tidak memenuhi, kebersihan lingkungan luar rumah yang tidak terjaga serta sedikitnya sinar matahari yang masuk ke dalam rumah, sehingga kumandan virus mudah untuk berkembangbiak dan menimbulkan penyakit bagi penghuninya. Faktor lainnya adalah kepadatan hunian yang melebihi ketentuan, juga dapat berpotensi untuk meningkatnya resiko ISPA.

Berdasarkan hasil penelitian ${ }^{7}$ hasil penelitian menunjukkan bahwa positif Common cold dikarenakan sanitasi rumah yang tidak sehat, diantaranya ventilasi rumah yang tidak memenuhi syarat Kepadatan hunian, Pencahayaan, dan adanya perokok. Menurut asumsi peneliti responden yang berisiko mengalami kejadian common cold adalah responden dengan kondisi sanitasi rumah yang tidak sehat. Sehingga dengan demi kian tentunya akan menambah tingginya jumlah kasus penyakit common cold. Berdasarkan hasil uji Chi Square untuk mengetahui hubungan kebersihan rumah dengan penyakit Common cold, diperoleh $p$-value $=0,000(\mathrm{P} \leq$ $0,05)$.

Hal ini juga sesuai dengan hasil penelitian ${ }^{12}$ yang menyatakan sanitasi rumah mempunyai nilai signifikan sebesar nilai $\mathrm{p}=0,001$ $(p<0,05)$. Dapat disimpulkan bahwa terdapat hubungan yang bermakna antara sanitasi rumah dengan kejadian Common cold. Hal ini berdasarkan pda hasil penelitian yang telah dilakukan dimana dari 58 responden mayoritas kejadian Common Cold sebanyak 40 responden (69,0\%). Tingginya angka kejadian Common Cold ini disebabkan karena kondisi sanitasi rumah responden memang sangat banyak yang tidak memenuhi syarat seperti tidak adanya sarana pembuangan air limbah, jarak sumur yang telalu dekat dengan septi tank, dan bahkan responden tidak memiliki sarana tempat pembuangan sampah.

Tuberkulosis dan ISPA (terutama common cold) erat kaitannya dengan kondisi sanitasi perumahan yang tidak memenuhi persyaratan kesehatan. Faktor resiko lain yang menyebabkan kasus tersebut juga bisa diakibatkan oleh persediaan air bersih dan sanitasi lingkungan yang tidak sehat. Upaya untuk mencegah munculnya faktor risiko yang menyebabkan timbulnya gangguan kesehatan telah tertuang dalam Kepmenkes RI No. 829/Menkes/SK/VII/1999 tentang Persyaratan Kesehatan Perumahan.

\section{KESIMPULAN}

Kesimpulan hasil penelitian ini adalah terdapat hubungan yang signifikan antara sanitasi rumah dengan kejadian Commond cold pada masyarakat yang berkunjung di Puskesmas Bandar Kabupaten Meriah. Untuk itu diharapkan masyarakat agar dapat meningkatkan atau menjaga sanitasi rumah yang sehat sehingga terhindar dari kejadian penyakit Common cold. 


\section{DAFTAR PUSTAKA}

1. Undang-Undang No 1 Tahun. Ep Ha M Ep Ha. 2011;

2. Riza Maula E, Rusdiana T. Terapi Herbal dan Alternatif pada Flu Ringan atau ISPA non-spesifik. Farmasetika.com (Online). 2016;1(2):7.

3. Janeiro DORIODE. World Health Statistics. 2018. 1-9 p.

4. Sakaguchi M, Shime N, Fujita N, Fujiki $\mathrm{S}$, Hashimoto S. Current problems in the diagnosis and treatment of hospitalacquired methicillin-resistant Staphylococcus aureus pneumonia. J Anesth. 2008;22(2):125-30.

5. Dewi PS, Darmadi IGW, Marwati NM. Hubungan Faktor-Faktor Sanitasi Rumah Dengan Kejadian Infeksi Saluran Pernapasan Akut Di Wilayah Kerja Puskesmas Iv Denpasar Selatan Tahun 2014. J Kesehat Lingkung. 2014;4(2):175-80.

6. Sinica AG. Hubungan karakteristik Rumah Dengan Kejadian ISPA Pada Balita dalam Keluarga perokok Di
Kelurahan Gundaling Kecamatan Berastagi Kabupaten Karo Tahun 2014. 2014;69(2013):49-53.

7. Polomulo sri zein. Hubungan Sanitasi Rumah dengan Kejadian ISPA. 2012;43-53.

8. Agungnisa A. Physical Sanitation of the House that Influence the Incidence of ARI in Children under Five in Kalianget Timur Village. J Kesehat Lingkung. 2019;11(1):1.

9. Kesehatan D, Aceh. Profil Kesehatan Aceh. Dk. 2019;53(9):1689-99.

10. Sofiyanti I, Ramadhani MA, Astuti FP. Edukasi Penatalaksanaan Common Cold dengan Terapi Herbal dan Terapi Pijat. Call Pap Semin Nas Kebidanan. 2020;1(1):44-50.

11. Seidel RE. Treatment of common colds. Hahnemannian. 1963;98:9-10.

12. Gapar Gede Sumetha . Putra NAP. Hubungan kualitas sanitasi rumah dengan kejadian penyakit infeksi saluran pernapasan akut (ISPA) di Wilayah kerja Puskesmas IV Denpasar Selatan Kota Denpasar. 2015;9(2):41-5. 